daughters of the more privileged to hand on to natives of all races the best traditions of the British way of life.

\section{Life After Retirement}

Towards the end of his career other prospects appear to the medical officer. He may have promotion, with its advantages and disadvantages. In addition, or instead of this, he may consider settling permanently in a Colony, for, although in the past it has been customary for the British official to be a bird of passage with an eye on a home in England for which he saves all he can, more recently Britons, like the Dutch, have been considering the advantages of driving a permanent stake in the land of their adoption. To many who remember the England of the period before the first world war the restrictions of nowadays are irksome, and permanent homes can be made in the healthier Colonies, in which one's link with Britain is maintained by the many and fast-developing air lines. Moreover, in such circumstances it is possible to continue to aid the backward peoples, which has been one's life work.

The man with a pension has no need to take all that he can from the land. The residential settler with an official's experience and no more than 50 acres to play with is the best type of settler. He can take a part in. local government, or he can develop a kind of manorial system in which he meets the people on the common ground of service' to the land, without obsequience on the one side or patronage on the other, and enjoy both the growth of his civilizing influence and the comfort of a well-served old age.

\section{Medical Memoranda}

\section{Thrombocytopenic Purpura in Infective Hepatitis}

Haemorrhagic manifestations during the course of hepatic disease are generally regarded as of serious prognostic import. Such instances are usually due to hypoprothrombinaemia and indicate considerable parenchymal disturbance, as in acute hepatic necrosis and leptospirochaetosis. Purpuric haemorrhages may, however, occur in comparatively mild hepatic diseases in association with increased capillary fragility with or without thrombocytopenia. This form of purpura depends on tissue susceptibility and is not related to the intensity of the primary infection, and therefore does not of itself indicate a grave prognosis.

\section{Case Report}

The patient, a housewife aged 30 , was sent into hospital as an emergency case by her doctor. He was perturbed about the association of jaundice and cutaneous petechiae. Vague upper abdominal pain had been present for a week before admission, and for the previous 48 hours she had vomited frequently, the vomit containing streaks of blood. Jaundice of the skin, anorexia, and malaise had been present for four days, and the patient had noticed petechiae over the trunk the day after the appearance of the jaundice. She gave no history of bruising or of haemorrhage before the onset of her illness.

Her regular menstrual period had begun a week previously and had persisted with menorrhagia, the duration and severity of the bleeding being quite unusual for her. She gave no history of limb pain or of dysuria, and she had received no recent transfusions or any parenteral injections. There was no history of indigestion or of contact with hepatic toxins of any kind.

On admission she was obviously jaundiced, and petechial haemorrhages were present over the trunk, limbs, and palate, with a few ecchymoses on her right shin. No abnormalities could be detected in her heart, chest, or central nervous system. The liver edge was just palpable and not tender. The spleen could not be felt. Her temperature was normal, but her pulse rate persistently slow. The urine was highly coloured and contained bilirubin, with urobilinogen and urobilin, and a moderate number of red blood cells. The capillary fragility test of Hess was positive. A blood count showed: red cells, 4,500,000; haemoglobin, $88 \%$; white cells, 3,800 , with a normal differential count ; van den Bergh, direct positive (immediate); serum bilirubin, $7 \mathrm{mg}$. per $100 \mathrm{ml}$.; alkaline phosphatase, 33.1 units (King-Armstrong); thymol turbidity, +4 units; total platelet count, 13,000 per c.mm. (Lempert Kristenson method-average normal variation, 170,000-320,000). Agglutination for Leptospira icterohaemorrhagiae and L. canicola was negative in all dilutions (Dr. J. C. Broome). Her blood group was B Rh-positive. The bleeding time was 24 minutes, and blood culture was sterile.

A diagnosis of infective hepatitis (I.H. virus), complicated by purpura haemorrhagica, was made. Treatment consisted of complete rest with a high-carbohydrate diet. On the following day she was given a pint $(570 \mathrm{ml}$.) of compatible blood, and a large painful ecchymosis developed at the site of transfusion. Water-soluble vitamin $\mathrm{K}$ was given by injection daily $(10 \mathrm{mg}$.).

Four days after admission the jaundice had noticeably improved and the purpura was less marked. Blood examination showed: haemoglobin, $84 \%$; red cells, 4,000,000 ; white cells, 4,800 per c.mm.; serum bilirubin, $2.6 \mathrm{mg}$. per $100 \mathrm{ml}$.; platelet count, 22,000; thymol turbidity, + 4; colloidal gold, +3 ; Takata-Ara, +++ . There was no evidence of circulating haemolysin. Blood culture was negative. Ten days after admission the patient was symptomfree, only slight conjunctival icterus being present, and the purpura had cleared. At no time was the spleen palpable. The platelet count then was 125,000 , the capillary fragility lests were negative, and the bleeding time was two minutes. $X$-ray films of the chest were normal.

The jaundice had disappeared by the 17 th day. Liverfunction tests: thymol turbidity, 2 units; colloidal gold, +2 ; Takata-Ara, +; Paul-Bunnell test negative. Sternal puncture showed a normal bone marrow with scanty megakaryocytes, which appeared normal. Platelets numbered 207,000 , with a normal blood count. Urine analysis was normal. The patient was discharged from hospital on the following day, and when seen three weeks later she was quite well, the blood count being: haemoglobin, $96 \%$; red cells, 4,720,000; white cells, 5,900.

\section{Comment}

It has been widely held that purpura occurs only in severe infections, but several recent papers have estoblished that this is incorrect. Ackroyd (1949) describes three cases of thrombocytopenic purpura complicating mild attacks of rubella, and Mills (1950) reports thrombocytopenic purpura occurring during an ordinary attack of measles, with full recovery. Furthermore, thrombocytopenia is often associated with diffuse hepatic disease. Snell, Vanzant, and Judd (1930) described haemorrhagic phenomena with thrombocytopenia occurring in obstructive biliary cirrhosis. Whitesell and Snell (1949) describe 29 cases of extrahepatic biliary obstruction, only four of which had thrombocytopenia, and 41 cases of hepatitis or cirrhosis, 37 of which had thrombocytopenia with increased capillary fragility or both. In their opinion a 
complete assessment of liver function should be made in all cases of idiopathic thrombocytopenic purpura before splenectomy is advised. In Traisman, Wheeler, and Fager's (1950) three cases of virus hepatitis in infancy one child had a platelet count of 30,000 .

The occurrence of purpura haemorrhagica in the above case of infective hepatitis may therefore have involved two precipitating factors - a virus infection and liver disease. It is likely, as Ackroyd states in his review of thrombocytopenia in acute infections, that fundamentally the haemorrhages are due to tissue sensitivity, and it was shown in this patient that the thrombocytopenia and the increased capillary fragility were more in evidence in the initia! stages of the infection. It is suggested that when a haemorrhagic tendency is present in a virus hepatitis the presence of thrombocytopenia and increased capillary fragility improves the otherwise serious prognosis, provided, of course, that haemorrhage into a vital organ, such as occurred in one of Ackroyd's (1949) cases, does not arise.

\section{G. Penrhyn Jones, M.D., M.R.C.P., D.C.H.,} Senior Medical Registrar.

E. Gerald Evans, M.R.C.S., L.R.C.P., Centre Pathologist.

Caernarvon and Anglesey

General Hospital, Bangor.

\section{REFERENCES}

Ackroyd, J. F. (1949). Quart. J. Med., n.s. 18, 299.

Mills, S. D. (1950). J. Pediat., 36, 35

Snell, A. M., Vanzant, F. R., and Judd, E. S. (1930). Med. Clin. N.'Amer., 13, 1417.

Traisman, A. S., Wheeler, R. C., and Fager, D. B. (1950). J. Pediat., 37, 174.

Whitesell, F. B., and Snell, A. M. (1949). J. Amer. med. Ass., 140, 1071 .

\section{Trichomonas Vaginalis Infections Treated with "Penotrane"}

Trichomonas vaginalis is one of the commonest causes of non-venereal vaginal discharge, and is a chronic problem to those treating such cases. Certain of the remedies already available seem to suit some patients and some suit others.

The bactericidal and mycoticidal properties of phenylmercuric salts are well known, phenylmercuric nitrate having been introduced clinically by Levine in 1933 . Goldberg et al. (1950a) demonstrated that combination with dinaphthylmethane disulphonic acid enhanced the bacteriostatic properties of the phenylmercuric ion. Furthermore, the crystalloid phenylmercuric salts possess little or no capacity to penetrate the tissues, whereas it has been shown (Goldberg et al., 1950b) that the colloidal phenylmercuric dinaphthylmethane disulphonate ("penotrane") passes through the living skin and enters deeply into the subdermal connective tissue, whilst its toxicity is of the order of that of colloidal silver.

These properties suggested the trial of penotrane in the treatment of trichomonal vaginitis, for which purpose we used a $0.1 \%$ aqueous solution and pessaries containing $0.2 \%$. The pessaries were specially made up in a base consisting of solid water-soluble polymers of ethylene glycol, similar to those employed by Siegler (1946) for the preparation of a sulphonamide ointment used for the treatment of vaginitis.

We treated 30 cases of vaginal discharge in which Trichomonas vaginalis was found on microscopical examination. Sixteen of these cases had been previously treated, principally with an arsenical vaginal compound, and had either relapsed or had reacted and responded unsatisfactorily. The treatment given consisted in painting the vagina with the aqueous solution of penotrane and inserting a penotrane pessary. Where possible the patient had paintings daily with insertion of a pessary, and where that was impracticable either painting once a week followed by the insertion of a pessary by the patient each night, or just the insertion of pessaries. There was a marked tendency to relapse after menstruation, but if the pessaries were used during the period this tendency was obviated. The insertion of pessaries every night for two weeks cleared the condition clinically and pathologically, but relapse occurred if the treatment was not continued. By continuing to use the pessaries on alternate nights and then gradually increasing the interval the patients were found to have no further symptoms. The average length of treatment was twelve weeks.

In nine cases the condition cleared, and at the time of writing no relapse has occurred, the first patients having been under observation for nine months. In 10 cases the condition cleared at first, but was followed by clinical or pathological relapse, usually after a menstrual period or a short lapse in treatment. Four cases improved, but their attendance has been so irregular that no definite conclusions can be drawn. One case showed improvement, but developed a cervical erosion after becoming negative to Trichomonas vaginalis, and treatment had to be changed. In three cases there was no improvement. Three patients did not return or were transferred after having shown improvement, but treatment was not completed.

In conclusion, it seems that penotrane has a place in the treatment of Trichomonas vaginalis infections, but at present relapses tend to occur, particularly after menstruation or if treatment is interrupted even for a short time. It is recognized, however, that relapses or recurrences, often due to reinfection, are frequently observed with other tried remedies, and penotrane appears to suit some patients who have not responded to other treatments.

Our thanks are due to Dr. M. M. Shaw for permission to carry out these trials on the patients of the Marlborough Clinic, and to Messrs. Ward. Blenkinsop and Co. Ltd. for the supplies of penotrane.

G. H. Platt, M.B., B.S., Assistant Medical Officer, V.D. Department.

J. SEamaN, .M.B., B.S.,

Registrar, V.D. Department.

J. W. Hadgraft, Ph.C., A.R.I.C., Chief Pharmacist.

Royal Free Hospital, London.

REFERENCES

Goldberg, A. A., Shapero, M., and Wilder, E. (1950a). J. Pharm. Pharmacol., 2, 20

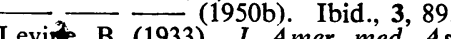

Amer. med. Ass. 101, 2109

Siegler, S. L. (1946). Amer. J. Obstet. Gynec., 52, 1.

The Journal of the American Medical Association (July 28 , p. 1231) reports a case of a negro woman suffering from mumps who gave birth to a child who was not infected. Mumps virus was isolated from the milk of the mother, and passed five times through eggs; this strain was used to induce mumps in two lactating monkeys. Neither of the infant monkeys showed any serum antibodies or signs of illness. The author suggests that either the virus failed to pass the placental barrier or the infant was insufficiently developed to have produced a detectable antibody response. 